\title{
Impact of Blue Ocean Strategy on Organizational Performance: A literature review toward implementation logic
}

\author{
Samsul Alam ${ }^{1}$, Mohammad Tariqul Islam² \\ ${ }^{I}$ (Lecturer of MIS, Dept. of Business Administration, Daffodil International University, Dhaka, Bangladesh) \\ ${ }^{2}$ (Assistant Professor, Dept. of Management Information Systems, University of Dhaka, Dhaka, Bangladesh)
}

\begin{abstract}
This study is based on the pros and cons of the Blue Ocean Strategy (BOS) that offers users a framework for creating uncontested market space and diverts the views from the current competition to the creation of innovative value and demand. The main objective of the study is to show the overall scenario of BOS and its impact on organizational performance. The study includes the history of BOS, comparison with Red Ocean Strategy (ROS), relevance of applying BOS, Applications, Critics, Findings, Recommendations and Conclusion. The Findings of the study tries to show the ultimate results of applying the BOS and the recommendations urge some precautions to apply BOS. The result found that BOS positively affects the organization performance if applied in organizations. Overall, the study is effective to decide the adoption of $B O S$ within the organization. The recommendation for the organization is to do an in-depth analysis on BOS before implementation to see the suitability considering the company size, industry condition, and adaptability.
\end{abstract}

Keywords: Blue Ocean Strategy, Organizational Performance, Red Ocean Strategy, Value Innovation, Creative Competition

\section{I.Introduction}

The business world is now very competitive. The decision makers of the business are changing their strategy to sustain in the competitive business world. In the past decades, some popular strategic frameworks for the creation of new business models have been developed. By this way, a new business model named "Blue Ocean Strategy" has been introduced by Kim and Mauborgne (2004a) which rapidly gained worldwide publicity and acceptance. This book was sold over 3.5 million times and published in 44 languages and is a bestseller across five continents. The BOS was selected as one of the 40 most influential books in the history of the People's Republic of China. "The famous book on BOS is apparently the new must, or at least an objective to pursue. It certainly was a 'technically' excellent marketing endeavor, based on the expedient of an original title, an intriguing subtitle, new labels for several old concepts and similar views expressed by other authors (Beckwith, 1997; Porter, 1996; Howard, Sheth, 1969; Levitt, 1975; Abell, 1980), it an intelligent and welltargeted communication campaign, and the prestige of the sponsoring business schools (Harvard and INSEAD). However, any reader of the book cannot avoid realizing that the statement '... make the competition irrelevant' is, in the best case, a little bold, even in specific market contexts mentioned by the authors in support of their thesis, and even more so in periods of economic crisis" (as cited in Gandellini \& Venanzi, 2011, p. 4).

BOS is a concept that enables organizations think and create innovation in their business that can assist organization to the financial and economic sectors which is the main concern of the firm to generate sustainable profit. The BOS offers users a framework for creating uncontested market place and change the concentration from the current competition to the creation of innovative value and demand where the traditional Red Ocean Strategy accustomed to involve in competition. Following the concept proposed in the book, several organizations in many sectors pursue this strategy for their business success.

With the endless endeavors of Kim and Mauborgne, BOS, a new strategy for achieving success through analyzing market to achieve goal got wide acceptance by many organizations. But it is seen that there is rare attempts to study showing the impact of BOS on organizational goal achievement. There is an absolute need to conduct a study justifying the BOS impact on organizational goal achievement which will further assist decision makers of business whether to go for BOS for their organization. In this study, this field is tried to cover and again analyze the suitability and applicability of BOS in organization.

The specific objective is to find out the impact of BOS implementation on the organizational performance and thus show the relevance of applying this new market strategy. The general objectives of the study have been identified as: to describe historical background and show the pros and cons of BOS, to compare BOS and traditional ROS and give a comparative theory, to describe the relevance of applying BOS in organization to generate and increase organizational performance, to see the real world organizational implications of BOS, to evaluate and measure the value of BOS in organizational goal achievement, to give critics of BOS application and recommendations for organizations. 
The study methodology involves with this paper is collection of data and information which analyzes only the secondary sources. In the operation of data collection function of current study, the qualitative method is used. In this regard, the secondary data are used to reach the conclusion. Secondary data sources are the published articles on the related factors in the conceptual framework of the study as well as electronic (e.g. Internet) and printed sources of data. The scope of the study covers the aspect of overall impact of organizations' performance those implemented BOS and show the relevance for implementing it in the organizations. Again, it compares the organizations' performance following traditional ROS.

This article makes sense that why organization should attempt to pursue BOS in their business. It outlines the basic theoretical framework of BOS, objectives of doing this research, area of the study focusing on the impact in organizations' goal achievement of BOS implementation. The remaining part of this study follows like in depth literature review including organization performance and value innovation, BOS vs. organization performance, BOS Implementation Cases \& Impact, and literature overview. Then the theoretical framework involving strategy, BOS, value innovation, and organization performance is described. After this section, an overview of BOS has given. Next section describes the relevance of applying BOS showing some cases. The final section involves the discussions including BOS critics, findings \& recommendations and make conclusion.

\subsection{Organization Performance \& Value Innovation}

\section{Review from the Related Literature}

"Performance measurement in the practical and theoretical spheres has attracted growing attention in recent years. The organizational effectiveness literature contains several models including the goal, system, strategic-constituencies, competing-values and ineffectiveness models" (Henri, 2004, p. 3\&34). Bowlby (2012) said "Organizational performance assessment is a practice-based framework that builds on the synergy between planning and assessment, and results in the discernment of impact and value” (p. 2). Organizational performance is measured based on quantitative (profitability, gross profit, return on asset (ROA), return on investment (ROI), return on equity (ROE), return on sale (ROS), revenue growth, market share, stock price, sales growth, export growth, liquidity and operational efficiency) and qualitative (job satisfaction, organizational commitment, and employee turnover) approaches which are approved by many researchers (Abu-Jarad, Yusof, \& Nikbin, 2010). "Strategic entrepreneurship has been defined as involving the identification and exploitation of opportunities, while simultaneously creating and sustaining a competitive advantage" (Kuratko \& Audretsch, 2009, p. 13). Kim \& Mouborgne (2003) said "knowledge-based organizations are totally dependent on the commitment and ideas of their employees" (p. 3). Rašula, Vukšić, \& Štemberger (2012) in their study done by collecting sample from 329 companies concluded that knowledge creation, accumulation, organization, and utilization enhance organization performance and the knowledge management practices measured through organization, technology and knowledge positively affect organizational performance. Meier \& O'Toole (2002) said "Management's relationship to performance is likely to be complex. The impact of management quality appears to be partially channeled through the mobilization of parental and community support" (p. 21). Park \& Shaw (2013) stated in their study that there is a significant negative relationship between turnover rates and organizational performance which is more negative for voluntary and reduction-in-force turnover than involuntary turnover that differs from organization and context-related factors such as types of employment system, dimensions of organizational performance, region, and entity size. The leaders can make change happen thought the coherent strategy of persuasion (Garvin \& Roberto, 2007). Timothy C., Okwu, Akpa, \& Nwankwere (2011) stated transactional leadership style has a significant positive effect on performance where transformational leadership style has a positive but insignificant effect and appreciated transactional leadership style is more appropriate for small scale enterprise's performance achievement with inbuilt strategies for transition to transformational leadership style with the development, growth, and maturity of the enterprises. Hurduzeu (2015) said that organization personnel inspired to work harder by transformational leaders to accomplish the highest level of organizational performance. Employee motivation and performance are important tools for long term organizational success which is positively related that if employees' empowerment and recognition increased, their willingness to work improved which in turn enhance organizational performance (Dobre, 2013). Ghafoor Khan, Ahmed Khan, \& Aslam Khan (2011) found from the literature that training and development in design of training and delivery style significantly and positively affect the organizational performance. Firm's performance influenced by strategic human resource management from various critical perspectives where human capital diagnose the needs for achieving sustainable competitive advantage that require implementing competitive strategy (Waiganjo, Mukulu, \& Kahiri, 2012). Bartel (2004) studied on bank's employee by site visit survey and concluded that there exists positive relationship between branch performance and employee satisfaction with the quality of performance, feedback, recognition, and communication. Sani's (2012) study on Nigerian insurance companies showing impact of organizational climate found that "strategic HRM alignment, line management training, career planning system and job definition are the key strategic HR practices that influence organizational performance" and the result suggests that organizational climate moderately influences 
relationship between strategic HRM practices and organizational performance. Organization culture has an influential impact on organization's processes, employees, and performance e.g., if employees follow the same norms and values of the organization which is based upon employee relationship, it can enhance organizational performance in achieving goal (Abu-Jarad, Yusof, \& Nikbin, 2010; Awadh \& Saad, 2013; Shahzad, Luqman, Khan, \& Shabbir, 2012). Ahmad's (2012) study made with 60 employees in COMSATS Institute of Information Technology found that "involvement is highly correlated with consistency and adaptability. Similarly, other dimensions of organizational culture have significantly positive relationship with the performance management practices". Aluko (2013) conducted a study on Nigerian textile firm taking interviews and structured questionnaire of 630 respondents found that culture is not the sole determinants of organizational performance; it is a multi -dimensional phenomenon where the economy, technology and the murky political climate all influence organizational performance significantly and much more than endogenous variable such as size, structure, and style of management. Again, they stated that workers were habituated with industrial way of life irrespective of organizational cultural background and they had high level of work commitment, low level of absenteeism and labor turnover, positive work beliefs, values, attitude and norms but this positiveness didn't translate high performance but finally there is a significantly positive relationship between culture and organizational performance. Because of inadequate technology and social infrastructures mentioning electricity and fuel crisis, the selected firms were not performing well. "Improvement in productivity is due not only to technology, but also to how it's integrated into the organization" (Gagnon \& Dragon, n.d., p. 19). Integration of diversity is relevant in world demographic patterns and work practices (Simons \& Rowland, 2011). Performance achievement in health care originations depends on the process redesign that generates performance-related information and content redefine of the information (Luttman, Siren, \& Laffel, 1994). Udegbe, Udegbe, Kehinde Ahmed, Ganiyat, \& Kareem (2012) performed a study using 100 small and large manufacturing and service companies operating in Lagos State of Nigeria and found that the surveyed companies emphasized on effective business communication to a reasonable extent which is related to the business category and its size. "In America, corporate performance has been deteriorating for decades. According to Deloitte's landmark study "The Shift Index" the aggregate return on assets of U.S. public companies has fallen below 1\%, to about a quarter of its 1965 level. As market power has moved from companies to consumers, and global competition has intensified, managers in almost all industries have market-creating moves (Kim \& Mauborgne, 2015, March, pp. 68-69)"'.

Gandellini \& Venanzi (2011) suggested a more or less effective and practical methodologies and found useful analytical method for identifying obstacles to buy goods based on client experience cycle of buyer behavior and utility levers including productivity, simplicity, convenience, risk, fun and image, and environmental friendliness. Lesser \& Storck (2001) suggested thinking community as an engine for developing social capital that leads behavioral changes and positively affect business performance. Osabiya (2015) conducted study on construction workers and identified ten critical factors like teamwork, work based on contract, supervision based on leadership, provision of equipment, communication, love, belongingness, opportunity to undertake challenging task, identification with goal, overtime that motivate them which has impact on productivity. Supply chain management strategy positively impact logistics performance which combined with impact of marketing performance that again impacts financial performance in positive way but neither SCM strategy nor logistics performance directly impact financial performance (Green, Whitten, \& Inman, 2008). Li, Ragu-Nathan, Ragu-Nathan, \& Subba Rao (2006) conducted a research on 196 organizations to show the impact of supply chain management (SCM) on competitive advantage and organizational performance and found that higher level of SCM leads to greater competitive advantage and improved organizational performance and again competitive advantage has a direct positive impact on organizational performance as competition is mainly based on the company's ability to maintain effective SCM.

Potential value creation in new product and services is created by making difference between benefit and cost in the view of customers. This value is exploited by market opportunity that depends on the success of the firm in obtaining competitive advantage over other firms which is must to outperform its rivals (Raith, Staak, \& Wilker, 2016). Value innovation is achieved using two economic laws of increasing marginal utility and decreasing marginal cost that confirm the perfect integration of high utility with low cost (Jian-jun \& Haimin, 2007). Kim \& Mauborgne (1999, January-February) stated that a systemic approach to value innovation helps organization break the traditional competition and thus become free. Aspara, Hietanen, Parvinen, \& Tikkanen (2008) emphasized in sales strategy on the creation of novel value by transforming traditional industry-specific roles, relationships, and business models is related to profitable growth. Savage \& Brommels (2008) found in their case study on Linköping Health University that it was able to create a divergent profile by eliminating, reducing, raising, and creating different aspects of curricula advocating the applicability of strategic management framework in medical education in understanding innovation. Lesser \& Storck (2001) conducted research on 7 organizations and said "it is widely recognized that communities of practice provide value to organizations" (p. 840). 


\subsection{Blue Ocean Strategy vs. Organization Performance}

Higher growth is a key goal of companies, governments, and societies (Lindič, Bavdaž, \& Kovačič, 2012). "Eliminating rivals is a risky strategy (Porter, 2008, January, p. 88). By competing in existing market, it is difficult for companies establish new market spaces and earn profits. To get relief of avowing being trapped in old markets, managers need to focus on attracting new customers, understand market creation, stop focusing on premium versus low cost strategies, and worry less about segmentation (Kim \& Mauborgne, 2015, March). Randall (2015) stated BOS as the first approach that got the right customer offering by linking value innovation and implied BOS strategist got sagacity in reconstructing market boundaries by exploring noncustomers rather looking for existing ones. The BOS role of innovation and value help organization survives in competitive market (Dehkordi, Rezvani, \& Behravan, 2012). Aspara, Hietanen, Parvinen, \& Tikkanen (2008) conducted first empirical study on BOS taking CEOs and sales directors of Finnish companies and the finding suggests that "active strategic networking aiming at creating totally new a) network roles, b) value creation logics, and c) benefits feeds into profitable growth among respondents". Their result suggests that "an increase in strategic emphasis on the creation of novel value by transforming traditional industry-specific roles, relationships, and business models has significantly positive impact $(\beta=1.17842)$ on firm profitable growth and an increase in strategic emphasis on selling the firm's expertise within business networks to create novel value, ultimately to consumers, may also have marginally significant positive effect $(\beta=.64358)$ on firm profitable growth". Agnihotri (2015) in his study suggested extended boundaries of BOS as well as advocated applicability of strategy canvas for all types of innovation and said BOS is applicable in emerging markets and it "can be created via radical innovation, disruptive innovation, frugal innovation, and purely differentiation strategy and focused differentiation strategy rather than only value innovation". He also explored the better option for profitability of BOS or sustainable competitive advantage. To make a smart strategic approach that matters centrally, creating Blue Ocean is appropriate that assist in exploring opportunities in the market space which is the root of growth. They recommended implementing BOS to break and speak out of box for those companies that want making difference, build future benefits from stakeholders (Low \& Ang, 2012). Borgianni, Cascini, \& Rotini (2012) presented in their study the past success stories of business using approach of BOS of the value innovation dimensions and mentioned certain strategies based on established or overlooked customer needs fulfillment provide greater market appraisal. Hsu, Lee, \& Chi (n.d.) applied concept of chance discovery and KeyGraph to discover hidden BOS for those decision makers who are unfamiliar with the concept and shown that BOS is not recognized with traditional approach and in contrary the subjects could easily find explicit scenarios of BOS, and recognize a few of implicit scenarios. Malaysian small businesses especially halal food producers could be transformed into global SME using BOS through value creation and low cost avoiding conventional way of intense competition (Mohd Dali, Bin Nooh, Nawai, \& Mohammad, n.d.). Gandellini \& Venanzi (2011) proposed a new strategy in their study namely Purple Ocean Strategy from the weaknesses identified in the BOS by developing and integrating that strategy to support small and medium enterprises' strategic realignment in the recovery phase after the great economic recession in 2008-2009 "that equips managers with the qualitative and quantitative tools for "piloting" the key competitive success factors [KCSFs], in terms of both managing the components of value, and measuring its economic and financial impact". This methodology allows identification and implementation of strategic move based on value creation and thus allows Blue Ocean firms generating profits and introduces 3 operational and quantifiable constructs of (i) investment curve specifying actual amount of investments having impact on KCSFs, (ii) value generated by investments based on relative importance assigned by market to KCSKs, and (iii) value/price ratio having impact on firm's market position based on demand elasticity and expected competitors' behavior assumptions. In ROS, serious contradiction between cost and differentiation exists that can be solved by using Theory of Inventive Problem Solving (TRIZ) which is similar to BOS in many ways (Hsiao, n.d.). Burke, Stel, \& Thurik (2010, May) did a research work on comparing the innovation strategy and competitive strategy testing model of Dutch retailing looking at profits and number of vendors of 41 shops types over 19 years period (1982-2000). Their findings were sustainable evidence for BOS. They found over that period that the average profitability and number of vendors both rose and fell and again "competition eventually erodes the profits from innovation. But that's a slow process, requiring 15 years or so, which suggests that it takes the better part of a generation for the blue-ocean approach to yield to competitive strategy" (p. 28) finally suggested business to consider blending of these two approaches.

\subsection{BOS Implementation Cases \& Impact}

A good strategy can put the organization on competitive map but appropriate execution can keep it there and most of the organizations struggle for implementation as they over relies on structural changes like reorganization (Neilson, Martin, \& Powers, n.d.). In the contemporary business, to be successful, must need to generate a creative value creation for and from customers that is achievable using BOS basically used to enhance customer acquisition, retention and in turn generate customer margin in turn make significant contribution to company profits (Yang \& Yang, 2011). Leavy (2005) stated that BOS is applicable to all types 
of industries from typical goods to business to business market that allows existing strategic planning process by drawing a strategy canvas. It represents a significant departure from status quo. From the launching of Wii video game, Nintendo started using Blue Ocean making competition irrelevant. The distinction from Wii is that Nintendo adopted better technology and built product though technically inferior became able to capture lion's share of market (O'Gorman, 2008). "A British retail group applied blue ocean leadership to redefine what effectiveness meant for frontline, midlevel, and senior leaders. The impact was significant. On the front line, for example, employee turnover dropped from about $40 \%$ to $11 \%$ in the first year, reducing recruitment and training costs by $50 \%$. Factoring in reduced absenteeism, the group saved more than US \$50 million in the first year, while customer satisfaction scores climbed by over 30\%" (Kim \& Mauborgne, 2014, May, p. 63). In general, leaders don't want to lose the talented employees which are key issue in underlying BOS. It is observed that leadership style is focusing on the employees' quality and behavioral styles that impede organizational focus of market and customer expectation. Using Blue Ocean leadership to connect to the market, the people who face market realities every day are asked for their direct input on the acts and activities of their leaders, and what they need from their leaders to effectively serve customers. Thus, the frontline managers will spend less time trying to please the boss and more time serving customers (Kim \& Mauborgne, 2014, November 13).

Saputri \& Mulyaningsih's (2015) study on merchandise business of Yogyakarta stated that a merchandise company implemented BOS where value innovation had a critical position where Kedai Digital created 3 distinguished value innovation namely free design, a unique location and a one-stop shopping concept that made the company leading position in the industry and made competition irrelevant instead of playing in the red ocean. They found 8 standard value within competition namely volume, price, prestige, quality, promotion, service, variation and on-time delivery. Wubben, Düsseldorf, \& Batterink (2012) studied on the uncontested market space of European fruit and vegetables industry and assessed the applicability of BOS. They found BOS framework enables the identification of ex ante an untapped market space targeting new buyer group of children and teenagers. Bourletidis (2014) conducted a research on BOS implementation in Greek region and stated BOS as an innovative strategic model can be implemented to create a sustainable development and successful entrepreneurial ventures due cluster. Lindič, Bavdaž, \& Kovačič (2012) studied two cases namely Slovenian gazelles and Amazon.com of successful high growth business suggested BOS to the policy maker to achieve high growth. In their study, the result revealed gap between micro and macro level growth and the finding called for change in specific size companies, industries, and business activities to intra-industry cooperation, collaboration to create value innovation of uncontested market. Chang (2010) conducted a study investigating cell phone markets using BOS and found bandit (i.e., unbranded or unknown-brand "white box" cellphones) introduced new business model changing the rule of game having low-cost and high value-added features. Butler (2008) did a study in UAE on both small and medium enterprise and multi-national enterprise sectors where new strategies and economy are implemented investigating the BOS. They mentioned that in BOS, revisit of value added activities are emphasized, some activities are eliminated and new activities introduced, noncustomers are targeted through innovation and changing strategy than competing intense competition. Koo, Koo, \& Luk (2008) introduced a holistic approach in their study to strategic formulation for Chinese manufactured consumer products deploying the application of SWOT analysis, balanced scorecard and BOS. Sharma, Seth, \& Niyazi (2010) conducted a study of Indian rural markets that used BOS showing role of entrepreneurship in economic development is going towards uncontested markets. They suggested that the core success of these rural markets development depends on the effective utilization of BOS. It provides effective ways to build a top-tier Universities worldwide extending distinctive characteristics of ethnic Universities that develop comparative advantage creating, protecting, and expanding BOS enhancing absolute advantage in building a top-tier Universities (Xiu-liang, 2007). Jian-jun \& Hai-min (2007) developed reengineering that reengineers new rule of demand and supply which lies in the change of utility-demand-supply-cost mechanism under noncompetitive market and regarded as the secret success of BOS. Kim, In, Baik, Kazman, \& Han (2008) stated in their study that techniques and practices used in value-innovative requirements engineering by focusing on deriving requirements from current known customers are not sufficient in enduring the existing highly competitive market and advocated the BOS concept that there is a potential market in a blue ocean where competition really doesn't exist. Kim, Yang, \& Kim (2008) conducted a case study on third-party logistics (3PL) provider, CJ-Global Logistics Service (CJ-GLS) of South Korea and stated the remarkable growth came from creating a Blue Ocean Market (3PL market) rather from existing red ocean market by attracting competitors' customers that the earlier incumbents ignored and by constructing new RFID-based business model and ubiquitous-oriented 3PL system.

\subsection{Literature Overview}

Obviously, there are quite a few researchers concerned with the idea of creating or developing new markets. Other researchers offered solutions in their paper how organizations could create new market space, some also used integrated theoretical frameworks (Navis \& Glynn, 2010) remotely comparable to the BOS that also offers frameworks and tools for creating uncontested market space. Companies should look to create new

DOI: 10.9790/487X-1901030119 $\quad$ www.iosrjournals.org $5 \mid$ Page


demand in uncontested market space (blue oceans) instead of competing head to head in an existing industry (red oceans). The strategy canvas is a tool that organizations can use to find a blue ocean for their business. When creating the strategy canvas they should look to eliminate or reduce things customers place little to no value on, raise factors that customers value highly, add new factors that customers would want but are currently not offered by the market (Kim and Mauborgne, 2005a). Kim and Mauborgne (2004a) stressed in their papers about the BOS perpetual that companies must stop to compete with each other. The reason for this is at the present technological stages, market spaces are shrinking, and the supply is overtaking demand due to globalization. More and more organizations join the existing markets, the competition is made on minimizing cost basis with falling prices as a result, but competing on price cannot be a long-term solution (Kim \& Mauborgne, 2004a).

The first theory leading to the BOS was the value innovation for the strategic logic of high growth in 1997. According to the fact that each article published by Kim and Mauborgne does not refer exactly to one topic, it is self-evident that the articles may not directly build one upon each other and developing one topic further with each article, but handling several related topics which may lead to the BOS. The blue oceans stand for completely new and undiscovered markets and opportunities with new value creations, new customer bases and no competition. Demand is created, growth is profitable and rapid, competition is irrelevant, rules of the game are not set, wide deep potential of market space that were not yet explored precisely. Blue ocean is vast, deep and powerful in terms of profitable growth and infinite (Kim \& Mauborgne, 2005b). Focusing on building competitive advantages detracts from reshaping old industries, driving young industries to new frontiers, and building entirely new industries. To achieve high growth, organizations need to break out of this vicious cycle of competitive benchmarking, imitation and pursuit. This calls for a fundamental change in vocabulary and organizations' strategic focus. Organizations need to drive their managers to pursue value innovation instead whereby differentiation and low cost are pursued simultaneously (Kim and Mauborgne, 2005b). In the BOS, Kim and Mauborgne (2004a) used several ideas of the "procedural justice, strategic decision making and the knowledge economy" from 1998, such as the fairness for individuals or the transparency of strategic decisions. Kim and Mauborgne (2004a) implied these ideas especially in the BOS tools. Due to the management risk of distrust, non-cooperation and even sabotage, the strategic decisions have to be fair and transparent. Therefore, Kim and Mauborgne (2004b) advice the strategy formulation process of the BOS to imply engagement, explanation and expectation clarity.

The only way to beat the competition is to stop trying to beat the competition. In red ocean, the industry boundaries are defined and accepted, and the competitive rules of the game are known. In blue ocean, competition is irrelevant because the rules of the game are waiting to be set. The organizations caught in the red ocean follow a conventional approach, racing to beat the competition by building a defensible position within the existing industry order. The creators of Blue Ocean, surprisingly, didn't use the competition as their benchmark. Instead of focusing on beating the competition, they focus on making the competition irrelevant by creating a leap in value for buyers and thus their organizations, thereby opening up new and uncontested market space (Halligan, 2006). When it comes to Red Ocean Strategies, the point isn't that these strategies are wrong, but that they are the strategies that everyone is using. None can stand out unless they find a strategy that gives them a wide-open blue ocean ahead (Moon, 2014). Kim and Mauborgne (2004a) point out that organizations not only have to outplay their competition, but furthermore completely ignore them by searching and entering new and uncontested markets. The main key therefore is to find out what customers seek when they buy a product or service and then define a total solution. Besides that, the process of creating and discovering blue ocean market is not about predicting and/or pre-allocating business trends. It is about leading managers who are able to reordering market realities in a fundamentally new way.

The organizations face steep challenge when they go for BOS implementation involving 4 hurdles of cognitive, limited resources, motivation and politics (Wallace, Castaneda and McGregor, 2009). A good strategy should equally focus on execution \& communication. In BOS, there are three simple characteristics or yard sticks used to evaluate strategies which are the focus, divergence and compelling tagline (Canopus Business Management Group, 2016). BOS encourages operational ideas and collective design from pioneers, migrators and settlers, and executes them corporately to create new value and eliminate ineffective outsourcing (Rosales, 2010). When the Principles of the BOS used properly, Kim and Mauborgne (2004b) mentioned expectable risks and ways to act on them. They stated that effective Blue Ocean Strategies should be about risk reduction and not about risk taking. To change the organization's strategy according to the BOS model, an organization has not only to change its focus from competition to new opportunities but also attach most importance on present noncustomers. For the strategic reorientation of the focus, benchmarking the competition is no option to achieve value and cost approach, because this would result in conventional competition. The changed focus from traditional competition and present customers should enable organizations and managers to be aware and get insight in order to develop new opportunities, create new customer values and uncontested market space beyond the traditional industry boundaries. 


\subsection{Strategy}

\section{Theoretical Framework}

Strategy is the creation of a unique position in carrying out a set of activities that require making tradeoffs in competing to choose what not to do, and involves in creating fit among these activities (Porter, 1996, November-December). Business strategy builds the roadmap to accomplish strategic goal achievement driven by competition, own capabilities, or innovation (Giannoulis \& Zdravkovic, n.d.). Strategic planning, an umbrella term, is the technical fit that gets part in organizational effectiveness and deals with organizational dilemmas and there are connections among leadership ideas, strategic thinking and traditional planning activities (Fairholm, 2009). Aithal \& Kumar (2015) said in strategic management, there are various types of strategies such as ROS, BOS, Green Ocean Strategy, Purple Ocean Strategy used for long term organizational sustainability and to deviate from competition. They generalized new strategy named Black Ocean Strategy for some organizations especially in developing countries that strive to achieve sustainability and to get relief of high intense problems at least for short term. Few companies have a clear strategic vision (Kim \& Mauborgne, 2000). Neilson, Martin, \& Powers (2008, June) showed in their research that organization fails to execute strategy as they straightly go to the structural reorganization and become indifferent in most powerful drivers for effectiveness like instead clarifying right decision and ensuring information flows where it is needed. Typically companies realize only about $60 \%$ value of their strategies because of defects and breakdowns in planning and execution which can be achieved more by following 7 rules including keeping strategy simple, challenging assumptions, speaking same language, discussing resource development early, identifying priorities, continuously monitoring performance, developing execution ability (Mankins \& Steele, 2005, July-August).

\subsection{Blue Ocean Strategy}

BOS or value innovation management is the strategy that reframes the strategic challenge from involving in competition to make competition irrelevant and provides a series of approaches that maximizes opportunity and minimizes risk (Leavy, 2005). "WHEN WE ASK PEOPLE to define what BOS is and what drives its success, we typically get one of three answers. Some see it as fundamentally about how to reconstruct market boundaries and offer a leap in value to buyers. Others see the essence of BOS as about unlocking business model innovation through strategic pricing, target costing, and the like so a company can seize new customers profitably. And still others see it as fundamentally about releasing the creativity, knowledge sharing, and voluntary cooperation of people through the proper approach to employees and partners. All three are correct answers" (Kim \& Mauborgne, 2015, Kindle Locations 2677-2682). Low \& Ang (2012) said "BOS is about growing demand and breaking away from the competition and having an open mind in business, and seeking all opportunities of creating uncontested market space, and in this way, it makes the competition irrelevant". Mi (2015) defined BOS as "BOS provides a theoretical framework and a practical roadmap for companies to break away from the cutthroat competition in existing industries and create new market space of profitable growth" and advocated that in market boundaries it breaks down the trade-off between value and cost through cognitive reconstruction of market elements under which view it argues that by strategic actions of micro-level actor, industry structure can be changed endogenously that requires alignment of value, profit, and people propositions of strategy in support of pursuing differentiation and low cost. "A new approach called blue ocean leadership (See Appendix 3) can release the sea of unexploited talent and energy in organizations. It involves a four step process that allows leaders to gain a clear understanding of just what changes it would take to bring out the best in their people, while conserving their most precious resource: time, an analytic tool, the Leadership Canvas, shows leaders what activities they need to eliminate, reduce, raise, and create to convert disengaged employees into engaged ones" (Kim \& Mauborgne, 2014, May, p. 63). Yang's (2012) study of selected hotels of Taiwan identified BOS characteristics including value perceptions, innovating distinctive added-value offerings, developing new market segments, branding and re-branding, creating a unique hotel ambience, adjusting distribution channels, and establishing strategic alliances.

\subsection{Value Innovation}

Innovation is the pioneer driver for long-term business growth which is widely recognized (Buisson \& Silberzahn, 2010). Kim \& Mauborgne (1997, January-February) investigated some high growth companies and their low growth competitors where they found that the low growth companies followed strategy in a traditional way of achieving competitive advantage that most companies do; on the other hand, the high growth companies regarded completion as irrelevant through strategic logic which the author named as value innovation (See Appendix 2). Kim \& Mouborgne (2000, September-October) said in their study "market-shaping innovations win by creating new customer pools, not by increasing the share of an existing customer pool" (p. 132). 


\subsection{Organization Performance}

Organization performance is used synonymously with productivity, efficiency, effectiveness, and competitiveness (Cooke, 2001). Majority of the organizations measure their performance in terms of effectiveness (See table 1 and 4 [Appendix 1]) in achieving their mission, objective and goals; efficiency in deploying resources; financially, and relevant viable to stakeholders and their changing needs. In the Organizational Assessment (OA) framework, these four aspects of performance are the key dimensions to organizational performance (deloach \& Thomson, 2014, February; Mitchell, 2002, August). There are a number of indicators and variables that reflect performance including strategy, leadership, employees, structure, quality, performance measurement, innovation and development, information technology, corporate governance, external environment and more where the frequency of use of these indicators directly balanced with the organizational performance (Gavrea, Ilieş, \& Stegerean, 2011).

TABLE 1: HIGHER VS. LOWER PERFORMANCE ORIENTATION FOR VALUES

\begin{tabular}{|c|c|}
\hline Higher Performance Orientation towards Value Tends to.. & Lower Performance Orientation towards Value Tends to.. \\
\hline $\begin{array}{l}\text { - Value and reward individual performance and } \\
\text { achievement; value training and development, } \\
\text { assertiveness, competitiveness, and materialism; taking } \\
\text { initiative, bonuses and financial rewards; that you do } \\
\text { more than who you are; being direct, explicit, and to the } \\
\text { point in communications } \\
\text { - Emphasize achieving results more than people } \\
\text { - Expect demanding targets } \\
\text { - Believe that individuals are in control } \\
\text { - Have a "can-do" attitude, performance appraisal } \\
\text { systems that view feedback as necessary for } \\
\text { improvement, monochromic approach to time, a sense of } \\
\text { urgency } \\
\text { - Believe that anyone can succeed if he/she tries hard } \\
\text { enough } \\
\text { - Attach little importance to age in promotional } \\
\text { decisions }\end{array}$ & $\begin{array}{l}\text { - Value societal and family relationships, harmony with } \\
\text { the environment rather than control, "attending the right } \\
\text { school" as an important success criterion, ambiguity and } \\
\text { subtlety in language and communications, who you are } \\
\text { more than what you do } \\
\text { - Emphasize loyalty and belongingness; seniority and } \\
\text { experience; tradition } \\
\text { - Have high respect for quality life; performance } \\
\text { appraisal systems that emphasize integrity, loyalty, and } \\
\text { cooperative spirit; high value for sympathy; a } \\
\text { polychromic approach to time; a low sense of urgency } \\
\text { - View feedback and appraisal as judgmental and } \\
\text { discomforting; assertiveness as socially unacceptable; } \\
\text { merit pay as potentially destructive to harmony } \\
\text { - Regard being motivated by money as inappropriate } \\
\text { - Associate competition with defeat and punishment } \\
\text { - Pay particular attention to age in promotional decisions }\end{array}$ \\
\hline
\end{tabular}

Adopted from Abu-Jarad, Yusof, \& Nikbin (2010)

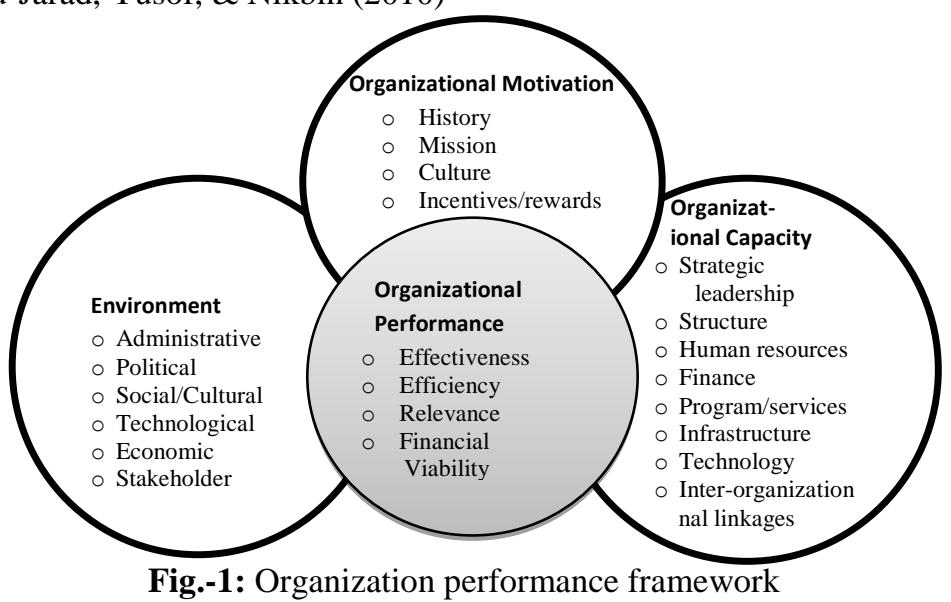

The schematic representation of performance framework (See figure 1) shows that performance is achieved in terms of effectiveness, efficiency, ongoing relevance and financial viability of organization where certain contextual forces likely organization capacity, external environmental forces, and internal organizational motivation drive it (See Appendix 4 for complementary paths to performance).

\subsection{History}

\section{An Overview of BOS}

Kreipke (2003) said Blue Oceans do not have to be entirely new (as cited in Straub, 2009, p. v). The BOS is a concept introduced by W. Kim and Renee Mauborgne in 2004 by publishing articles and well sold book (2005) over 3.5 million copies and published in a record-breaking 44 languages that is also awarded as the best business book of 2005 and top ten business book of 2005 by amazon.com. This book is based on a study of 150 strategic moves spanning more than 100 years and 30 industries. According to the authors, it provides the 
analytical frameworks and tools to create and enter new market space. Using the BOS, each company should be able to find unique ways to discover new market space. Important to note, what all companies have in common is that they need to focus on non-customers, and also need to be aware that most blue markets are often created within of existing red oceans (Kim \& Mauborgne, 2004a). It is also to consider that the BOS may combine beneficial features from two separate already existing markets, to create a single unique product with advantages over the competition in both markets (Agadoni \& Agadoni, 2016). From their researches Kim and Mauborgne (2004a) developed their BOS model, which provides a series of tools and frameworks as guidance for companies to create unique strategies to create and generate their own uncontested markets.

\subsection{Idea of and Comparison between ROS and BOS}

There are two types of strategies - structuralist (red ocean); assumption that operating environment is given and reconstructionist (blue ocean); with the assumption to shape the environment - between which should be appropriate depends on the environmental attractiveness, the capabilities of the organizations have, and whether it has a strategic orientation for competing or for innovating. Structuralist strategy requires people, value, and profit focusing low cost or differentiation where reconstructionist strategy focuses on the both (Kim, 2010). There are two distinct strategies for business world - ROS and BOS (See Table 2) - with the thinking that red ocean is the traditional overcrowded known market space where industry is in a specific boundary and there is a competitive game plan for companies involving a competition to outperform rivals for capturing market demand that limit high performance as well as make increasing competition a bloody ocean; and on contrary, blue ocean is a unseen market arena of uncontested market space without taking competitor as a rival or making competition irrelevant achieve demand and breaking the traditional industry boundary create new industry within the existing industries beyond red ocean that is the notion of this new industry is in deep waters.

In Blue Ocean, there are a number of opportunities for companies to a profitably rapid growth. Whether companies conscious of the fact, always blue ocean has an immense application in business space since earlier days. Both strategies are coexisted and also will always in future (Kim and Mauborgne, 2005a). BOS is the method of creating value and exploring non-customers which create the business model canvas showing a complete image of dependable factors for ensuring alignment. The noncustomers for this new market can even be isolated in a Business Model Canvas together with the development of an empathy map in order to gain a deeper insight (Berry, 2015). BOS is the concept of pursuing differentiation and low cost simultaneously. It emphasizes on innovation for both new entrant and incumbent by offering a systematic and reproducible methodologies and processes. It is about reducing costs while at the same time increasing customer value. It is designed to be visual so that it becomes easy to effectively execute collective wisdom of companies (Kim and Mauborgne, 2004a).

Features of ROS include the traditional way of achieving organization performance through intense competition in existing market, beat the rivals, exploit existing demand, make the value or cost trade-off, align the company's functional process activities with its strategic choice of low-cost or differentiation. On the other hand, BOS has the profound contemporary features to achieving organizational performance though having clearly strong focus, divergence, compelling tagline, creating uncontested market space, making competition irrelevant, creating and capturing new demand, breaking value or cost trade-off, aligning whole system of organizational functional activities in pursuit of differentiation and cost.

TABle 2: ShiFTING StRATEGY FOCUS FROM TRADITIONAL COMPETITION TO CREATING NeW MARKET SPACE

\begin{tabular}{|l|l|l|}
\hline $\begin{array}{l}\text { Competition in } \\
\text { Conventional Boundaries }\end{array}$ & \multicolumn{1}{|c|}{$\begin{array}{c}\text { Head-to-Head } \\
\text { Competition }\end{array}$} \\
\hline Industry & Focus on industry rivals & Creating New Market Space \\
\hline Strategic group & $\begin{array}{l}\text { Focus on competitive position within } \\
\text { strategic group }\end{array}$ & Industry strategic group focus \\
\hline Buyer group & Focus on serving better the buyer group & Industry buyer group redefined \\
\hline $\begin{array}{l}\text { Product and service } \\
\text { offerings }\end{array}$ & $\begin{array}{l}\text { Focus on product and service value } \\
\text { maximization within industry boundaries }\end{array}$ & $\begin{array}{l}\text { Look across complementary products } \\
\text { and service offerings beyond industry } \\
\text { boundaries }\end{array}$ \\
\hline $\begin{array}{l}\text { Industry functional and } \\
\text { emotional orientation }\end{array}$ & $\begin{array}{l}\text { Focus on improved price-performance with } \\
\text { functional-emotional orientation of industry }\end{array}$ & $\begin{array}{l}\text { Industry functional-emotional } \\
\text { orientation rethinking }\end{array}$ \\
\hline Time & $\begin{array}{l}\text { Focus on adapting to external trends as they } \\
\text { occur }\end{array}$ & $\begin{array}{l}\text { Participation in shaping external trends } \\
\text { over time }\end{array}$ \\
\hline
\end{tabular}

Adapted from Kim \& Mauborgne (1999, January-February) 


\section{Relevance of Applying BOS in Organization}

The best way to describe the attractiveness of the blue oceans is to analyze the Blue Ocean Paradox, shown up by Kim and Mauborgne during a study in 2005. The result of the study showed that only $14 \%$ of all studied business launches were made within the Blue Ocean markets, but these $14 \%$ achieved $38 \%$ revenue impact and about $62 \%$ of profit impact. Compared to the majority of $86 \%$ business launches in red oceans, which were able to get $39 \%$ of the total profit impact (Kim \& Mauborgne, 2004a). This paradox seems to be very appealing especially on businessmen, who are always looking for ways to increase their revenues and profits. Companies should stop competing with each other. The reason for this is that at the present technological stages are the shrinking market spaces, and the supply is overtaking demand due to globalization. More and more companies join the existing markets, the competition is made on minimizing cost basis with falling prices as a result, but competing on price cannot be a long-term solution (Kim \& Mauborgne, 2004a). Other researchers mention that the BOS is most effective when markets are saturated or in decline. Therefore a company should target completely new customer groups to increase their customer base (Agadoni and Agadoni, 2016). Kim and Mauborgne (2004a) pointed out those companies not only have to outplay their competition, but furthermore completely ignore them by searching and entering new and uncontested markets. The main key therefore is to find out 1) what customers seek when they buy a product or service and then 2) define a total solution. Besides that, the process of creating and discovering blue ocean markets is not about predicting and/or pre-allocating business trends. It is about leading managers who are able to reordering market realities in a fundamentally new way. BOS creates uncontested market space, makes competition irrelevant, creates and captures new demand, break the value-cost trade off, pursues differentiation and low cost that insist ventures apply and implement this strategy for their improved performance. From their researches, Kim and Mauborgne (2004a) developed their BOS model, which provides a series of tools and frameworks as guidance for companies to create unique strategies to create and generate their own uncontested markets. Blue Ocean has been successfully applied to organizations like VIAT (Value Innovation Action Tank) of Singaporean non-profit organization, IKEA-furniture industry, Starbucks, Phillips that found to be good organizational performance (Basri, Ghadzali, \& Ismail, 2011).

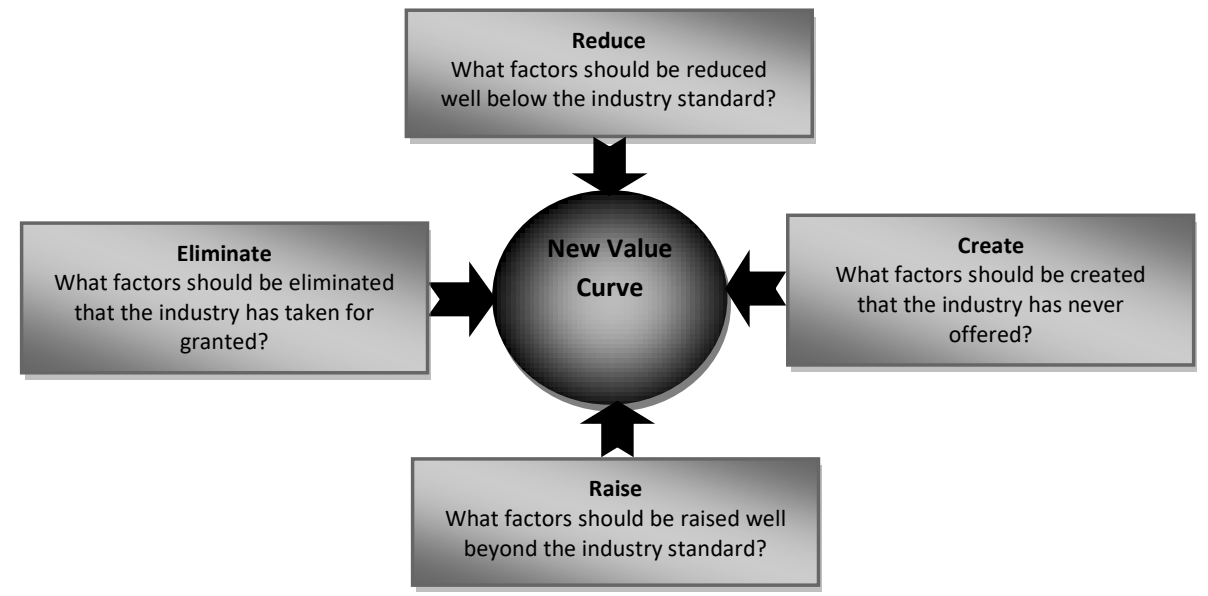

Fig.-2: 4 Key dimensions for creating value curve (kim \& mauborgne, 1999, january-february, p. 3)

The value creation requires 4 dimensional action frameworks (See figure 2). The first dimension is to eliminate factors which are below the industry standard making bound long term unnecessary cost to the firm despite having no meaning in earning profits or value. Next is to reduce factors that are industry below standard. Thirdly, firms have to raise those factors that are industry above standard having valuable meaning to customers. The rest are those factors to be created which the industry never offered that can create new customer demand for goods. Thus, applying the Eliminate-Reduce-Raise-Create (ERRC) Grid is appropriate to identify new Blue Ocean market. It pushes firms to create new value curve.

The Blue Ocean Leadership Grid (See figure 3) is an "analytic tool that challenges people to think about which acts and activities leaders should do less of because they hold people back, and which leaders should do more of because they inspire people to give their all" (Kim \& Mauborgne, 2014, May). 


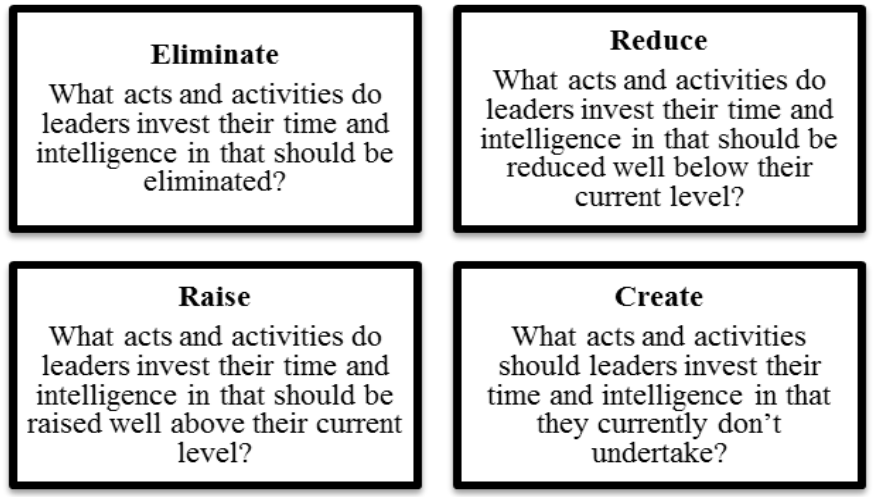

Fig.-3: the blue ocean leadership grid (kim \& mauborgne, 2014, may)

Effective leaders' activities tend toward creating value using employees assigned to four categories in grid. The leadership grid provides a concrete, visual framework in improving leaders' performance. If fairly used, it can make the changes easy than the traditional top-down approaches. The unnecessary and less important tasks of leader need be eliminated. Leaders' tasks that contribute less value but require more effort and talent of leaders should be reduced. The activities that the leader pursues higher value to organization should be raised. And the value that the leader has the potential to add value which are not currently done and also not done in earlier should be created for higher value. The categories of the leadership grid are achievable by the Blue Ocean leaders. This leadership approach allows transformation in less effort and time as leaders do not try altering people or breaking habit for lifetime rather they change the tasks simply. The scalability of this Blue Ocean leadership allows leaders launch quickly whatever he/she belongs to management level just can start and can awaken the sleeping potential of personnel.

There are some real world examples (Keller, 2016) of successful BOS application. Some of them are stated below:

\subsection{Cirque du Soleil}

The company was founded in 1984 by Guy Lailberte. Initially in 1980, the group toured performing as "The Wanders" before they incorporated. During those years they experience financial hardship and needed government funding to stay afloat which they received in 1983. In 1984 they changed their performance to one without animals and one that focused on character driven theatrical approach (See figure 4). By using the BOS it has become the largest theatrical producer in the world with over US \$1 Billion in revenue annually as of 2011.

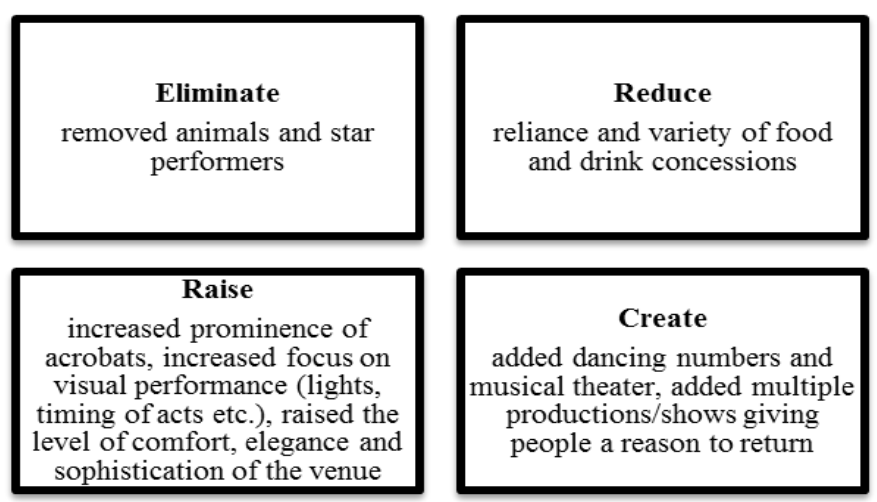

Fig.-4: Product changes using ERRC grid

Company achieved total return on Investment (ROI) of $35000 \%$ where investment is US \$1.5 million (from the Canadian government to change to a theatrical focused circus) and Profit US \$175 million/year (2008 estimate) estimating ROI per year of $21 \%$.

\subsection{The Nintendo Wii}

Nintendo was founded in 1889 and at the time made handmade hanafuda cards. It is now the world's largest video game company by revenue. Nintenedo tried many different businesses before finding success in video games with the launch of the Nintendo Entertainment System in 1983 and revolutionized both the company and the industry. In 2006, Nintendo introduced the Nintendo Wii as well as several advanced, 
revolutionary features with the Wii system. The most notable of these was the wireless motion-sensitive remote controllers. In addition Nintendo took a BOS focusing on targeting families (including the elderly) as opposed to the young male hard core gamer that the industry had been focusing on at that time (See figure 5).

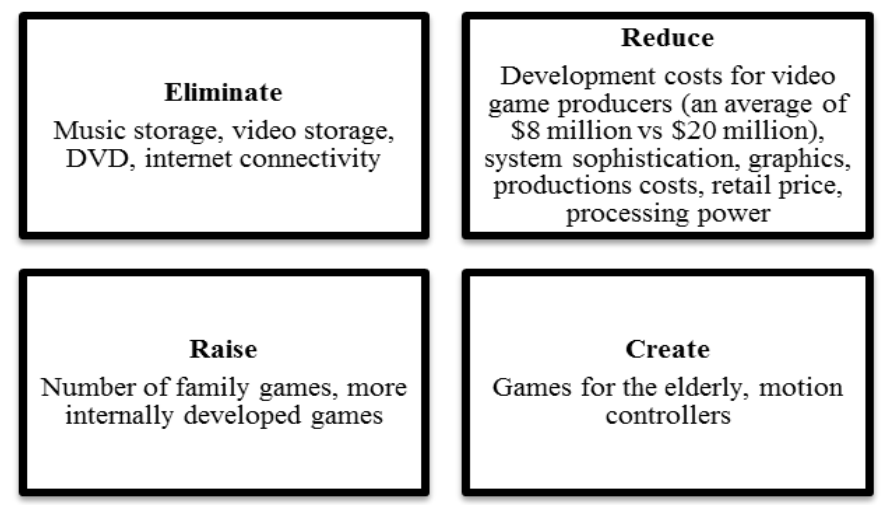

Fig.-5: Product changes using ERRC grid

Company achieved 3 years' ROI of $130 \%$ or $32 \%$ per year excluding over 250 Million Wii games sold by Nintendo that they have sold since launch where investment is US \$448 million (estimate based on annual reports with US \$124 million research \& development costs and US \$394 million marketing costs) and profit US \$1,032 Million (it is estimated Nintendo makes US \$50 per Wii console sold and it is estimated that there were 100.3 consoles sold as of October $30^{\text {th }}, 2013$ and that was US \$67.4 Million in 3 years after launch). 3 Year ROI including Game Sales found $800 \%$ or $108 \%$ /year (assuming a contribution margin $30 \%$ and average retail price of US $\$ 40$ ).

\subsection{Apple}

The company was founded in 1976 by Steve Jobs and Steve Wozniak. It is the largest company in the world by market capitalization. For almost two decades, Apple focused on manufacturing computer software systems until 2001 when it implemented a BOS and launched the iPod music player (See figure 6), which revolutionized how people listened to music.

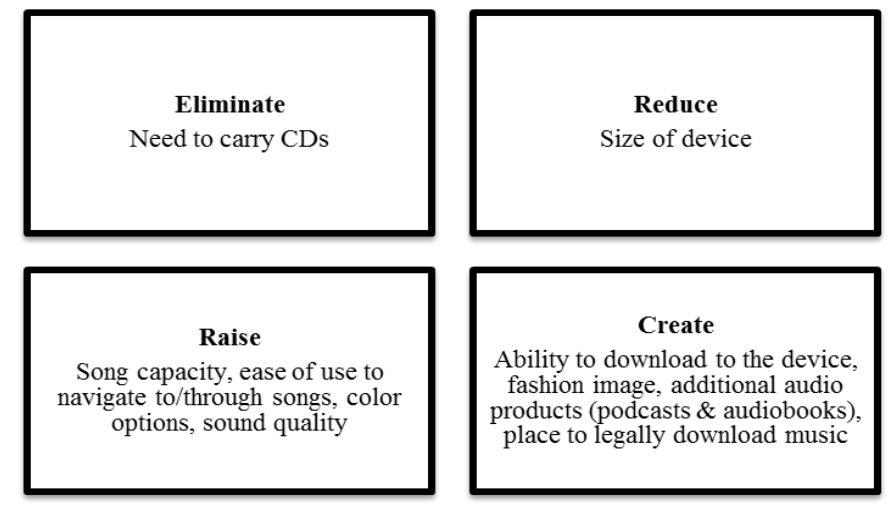

Fig.-6: Product changes (iPad) using ERRC grid

Company achieved ROI of $28.6 \%$ per year (given launched in 2001 and sales data as of 2012) where investment was US \$3.3 Billion (development costs estimated at US \$150 Million, and US \$285 million in advertising per year) and profit US \$52.5 Billion (As of September 2012, Apple had sold US \$350 Million iPods, assuming an average revenue per unit of US \$150).

\subsection{Netflix}

The company was founded in 1997 in Silicon Valley by Marc Randolph and Reed Hastings. Initially the company operated a pay per rent movie rental website where they would ship the movie to the customer and they would ship it back to them. Netflix then moved to a monthly subscription model where they could request to be shipped a certain number of videos per month for their monthly fee in 1999. Sales began to grow and the company turned its first profit in 2003 with sales of US \$272 million and a profit of US \$6.5 million. In 2007 Netflix began streaming video online so that subscribers could watch movies over the internet. By using the BOS (See figure 7) it has become the movie streaming service in the world with US $\$ 3.6$ billion in revenue and 
US \$17 million in profit in 2012 .

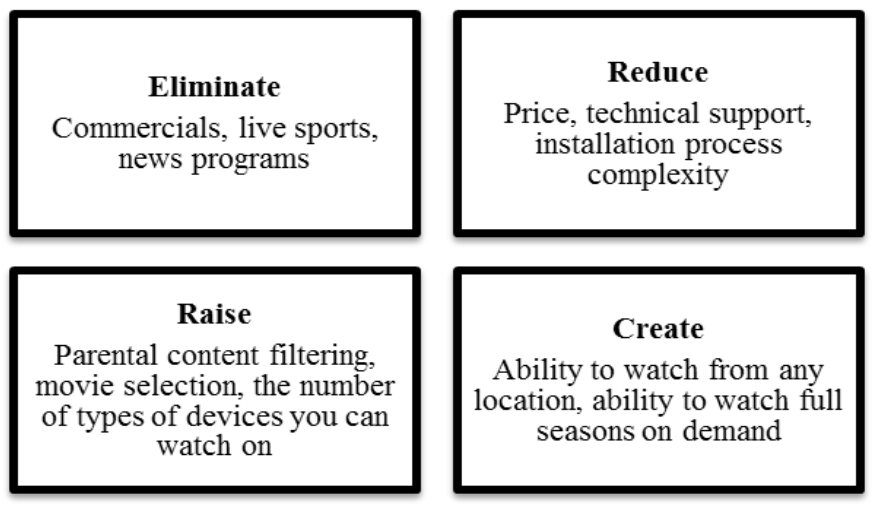

Fig.-7: Product changes using ERRC grid

Company achieved ROI of $114 \%$ per year assuming profits stay at the US \$112 Million per year, most likely they increase where investment was US \$97.4 Million (US \$2.5 Million (Initial Investment) plus US \$94.9 Million in stock offerings) and profit was US \$112 Million/Year (As of 2013).

Basri, Ghadzali, \& Ismail (2011) in their study suggested a Malaysian Universiti Sains Malaysia (USM) library to implement BOS Eliminate-Reduce-Raise-Create grid (See figure 8) focusing on Create grid where value innovation takes place for better performance. In their opinion, libraries should raise standard of activities higher than common standard. They should offer higher values and deliver at low cost than their competitors. Libraries should reduce and eliminate all the insignificant activities and create unique customer values. The application of the BOS grid is essential for serving customers better with best quality, and satisfaction that is especially appropriate for matured libraries those having decreasing customer loyalty.

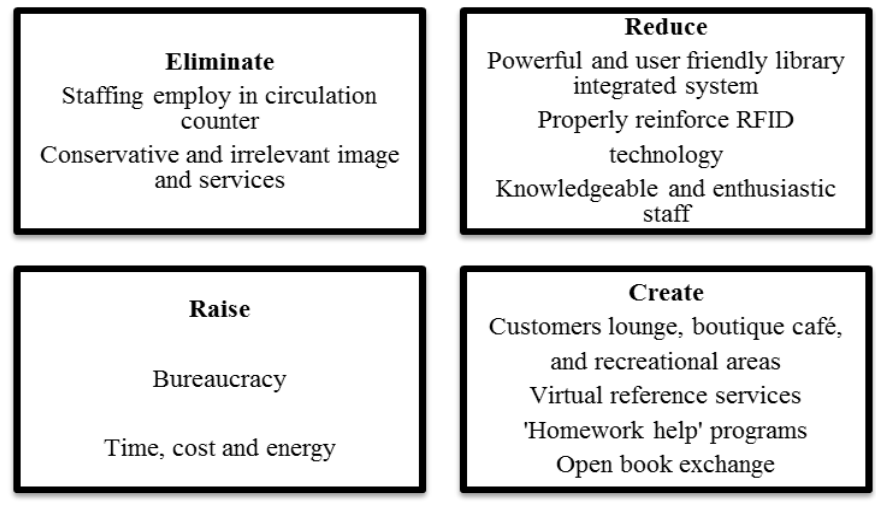

Fig.-8: The BOS application grid of USM library (basri, ghadzali, \& ismail, 2011)

TABLE 3: ORGANIZATIONS THAT ACHIEVED SUCCESS APPLYING BOS (KABUKIN, 2014)

\begin{tabular}{|l|l|l|}
\hline Name and Type of Organization & Origin & Remarks \\
\hline $\begin{array}{l}\text { Cirque du Soleil } \\
\text { (Circus entertainment business) }\end{array}$ & $\begin{array}{l}\text { Canadian } \\
\text { company }\end{array}$ & $\begin{array}{l}\text { Implementation of BOS by IDA } \\
\text { succeeded }\end{array}$ \\
\hline $\begin{array}{l}\text { Apple } \\
\text { (Technology based company) }\end{array}$ & $\begin{array}{l}\text { USA } \\
\text { company }\end{array}$ & $\begin{array}{l}\text { Apple states itself that it used the BOS model to sustain its } \\
\text { innovation process }\end{array}$ \\
\hline $\begin{array}{l}\text { Google } \\
\text { (Information based company) }\end{array}$ & $\begin{array}{l}\text { USA } \\
\text { company }\end{array}$ & $\begin{array}{l}\text { Google is using the main ideas of BOS to develop constant } \\
\text { innovations }\end{array}$ \\
\hline $\begin{array}{l}\text { Amazon.com } \\
\text { (Retailing business) }\end{array}$ & $\begin{array}{l}\text { USA } \\
\text { company }\end{array}$ & $\begin{array}{l}\text { Research at Amazon.com case showed that companies use BOS to } \\
\text { grow faster. }\end{array}$ \\
\hline $\begin{array}{l}\text { Tata Motors } \\
\text { (Multinational automotive } \\
\text { manufacturing company) }\end{array}$ & $\begin{array}{l}\text { Indian } \\
\text { company }\end{array}$ & $\begin{array}{l}\text { Tata Motors became famous worldwide by introducing the Tata } \\
\text { Nano, the most inexpensive car in the world }\end{array}$ \\
\hline $\begin{array}{l}\text { AIDA Cruiser } \\
\text { (Tourism crousing) }\end{array}$ & $\begin{array}{l}\text { British- } \\
\text { American } \\
\text { company }\end{array}$ & Implementation of BOS by AIDA succeeded \\
\hline $\begin{array}{l}\text { Southwest Airline } \\
\text { (Low-Cost carrier) }\end{array}$ & $\begin{array}{l}\text { USA } \\
\text { company }\end{array}$ & $\begin{array}{l}\text { SW Airlines created a blue ocean by offering the speed of air travel } \\
\text { with the low cost \& flexibility of driving }\end{array}$ \\
\hline
\end{tabular}




\begin{tabular}{|c|c|c|}
\hline Name and Type of Organization & Origin & Remarks \\
\hline $\begin{array}{l}\text { The body shop } \\
\text { (Cosmetic industry) }\end{array}$ & $\begin{array}{l}\text { Great Britain } \\
\text { company }\end{array}$ & $\begin{array}{l}\text { Created functional cosmetics that defied the industry which sold } \\
\text { emotionally appealing cosmetics }\end{array}$ \\
\hline $\begin{array}{l}\text { Casella Wines } \\
\text { (Wine industry) }\end{array}$ & $\begin{array}{l}\text { Australian } \\
\text { company }\end{array}$ & Casella wines created Yellow tail, a blue ocean wine that succeeded \\
\hline $\begin{array}{l}\text { Nintendo } \\
\text { (Home entertainment) }\end{array}$ & $\begin{array}{l}\text { Japanese } \\
\text { company }\end{array}$ & Nintendo invented the Wii using the BOS as a strategy \\
\hline $\begin{array}{l}\text { HBO } \\
\text { (Television) }\end{array}$ & $\begin{array}{l}\text { USA } \\
\text { company }\end{array}$ & $\begin{array}{l}\text { Produced "Sex and the City" for an uncontested market of } \\
\text { television consumers: single, urban professional women }\end{array}$ \\
\hline $\begin{array}{l}\text { Callaway Golf } \\
\text { (Golf equipment industry) }\end{array}$ & $\begin{array}{l}\text { USA } \\
\text { company }\end{array}$ & Creates "Big Bertha", a golf club that attracted new customers \\
\hline $\begin{array}{l}\text { Curves } \\
\text { (Fitness centre) }\end{array}$ & $\begin{array}{l}\text { USA } \\
\text { company }\end{array}$ & Fitness centre only for woman that succeeded and grew rapidly \\
\hline $\begin{array}{l}\text { Micromax } \\
\text { (Consumer electronics } \\
\text { company) }\end{array}$ & $\begin{array}{l}\text { Indian } \\
\text { company }\end{array}$ & $\begin{array}{l}\text { Company known for using the BOS increased its market share in } \\
\text { the smartphone segment in India to } 22 \% \text {. }\end{array}$ \\
\hline $\begin{array}{l}\text { ICICI Bank } \\
\text { (Financial institute) }\end{array}$ & $\begin{array}{l}\text { Indian } \\
\text { company } \\
\end{array}$ & $\begin{array}{l}\text { ICICI Bank growing during and after the financial crisis, using the } \\
\text { BOS frameworks }\end{array}$ \\
\hline $\begin{array}{l}\text { Campus Monterrey } \\
\text { (University) }\end{array}$ & $\begin{array}{l}\text { Mexican } \\
\text { organization }\end{array}$ & $\begin{array}{l}\text { Using BOS to explore new business niches like the exotic fruit, } \\
\text { Anacardium Occidentale in Mexico. }\end{array}$ \\
\hline $\begin{array}{l}\text { SimoBIT } \\
\text { (Governmental) }\end{array}$ & $\begin{array}{l}\text { German } \\
\text { company }\end{array}$ & $\begin{array}{l}\text { Use of BOS in governmental institutions as a strategy for resolving } \\
\text { market barriers }\end{array}$ \\
\hline $\begin{array}{l}\text { Starwood } \\
\text { (Hotel and leisure) }\end{array}$ & $\begin{array}{l}\text { USA } \\
\text { company }\end{array}$ & $\begin{array}{l}\text { Company saving space and cost due to using Blue Ocean basic } \\
\text { ideas. }\end{array}$ \\
\hline $\begin{array}{l}\mathrm{MM} \\
\text { (Leisure and tourism) }\end{array}$ & $\begin{array}{l}\text { USA } \\
\text { company }\end{array}$ & $\begin{array}{l}3 \mathrm{M} \text { is known for its culture that had created ground breaking } \\
\text { products, even more with the use of BOS. }\end{array}$ \\
\hline $\begin{array}{l}\text { China Mobile } \\
\text { (Telecommunication) }\end{array}$ & $\begin{array}{l}\text { Chinese } \\
\text { company }\end{array}$ & $\begin{array}{l}\text { China's opening markets and new opportunities allow lots of blue } \\
\text { oceans, also for China Mobile. }\end{array}$ \\
\hline $\begin{array}{l}\text { Pitney Bowes } \\
\text { (Technonogy) }\end{array}$ & $\begin{array}{l}\text { USA } \\
\text { company }\end{array}$ & $\begin{array}{l}\text { The Executive Chairman of PB credits the BOS especially for the } \\
\text { development of the internal advanced concept \& technology group } \\
\text { and its innovative activities. }\end{array}$ \\
\hline $\begin{array}{l}\text { Fabindia } \\
\text { (Retailing) }\end{array}$ & $\begin{array}{l}\text { Indian } \\
\text { company }\end{array}$ & $\begin{array}{l}\text { Using the BOS, Fabindia created in } 2007 \text { community owned by } \\
\text { floating wholly owned subsidiary companies. }\end{array}$ \\
\hline $\begin{array}{l}\text { Shaadi.com } \\
\text { (Matrimonial website) }\end{array}$ & $\begin{array}{l}\text { Indian } \\
\text { company }\end{array}$ & $\begin{array}{l}\text { Shaadi.com is known as the world's largest matrimonial website } \\
\text { using BOS to create uncontested markets. }\end{array}$ \\
\hline
\end{tabular}

\subsection{Critics of BOS}

\section{Discussions and Conclusions}

BOS entitles to the outstanding business notions to sustain in the competitive business world. But it is not free from criticism. Burke, Van Stel, \& Thurik, (2009) in their study mentioned that the literature of BOS does not provide distinction between short term and long term strategic time horizons, the validity of BOS depends on irrelevant predictions and beliefs in sufficient Blue Ocean Markets, the BOS Lacks in evidence, the Blue Ocean Markets are seldom purely uncontested, the ambiguous definition of innovation existed in the BOS. Herman (2008) said that the basic notion is not new and described misleading Customers and Demand are not created but captured from other markets, no Blue Ocean markets can be generated, competition is always present, in the long term, BOS does not achieve perfect results, the Period of BOS success is the period of unfair advantage, the basic idea of BOS is described in differentiation strategy.

\subsection{Findings}

The study found that the BOS provides benefits in great extent to the industry. The BOS can be used in for profit industries, not for profit industries and even for the public sector. This strategy is based on a decade long study of more than 150 strategic moves spanning more than 30 industries over 100 years. It seeks to break the value cost tradeoff by eliminating and lessening factors and organization competes on and augmenting and generating factors the organization has never offered which is called the value innovation, provides the systematic tools and frameworks to break away from the competition and generate a blue ocean of uncontested market space, follows a four step process to break away the competition and generate a blue ocean of strong profitable growth, provides an exact mechanism to reduce risks and increase the opportunity to reach in the culmination of success, makes the process non intimidating and an effective path for facilitating execution into strategy and the collective wisdom of a company, shows how to align the three strategy propositions- value, profit and people to ensure that the organization is aligned around the new strategy and it creates a win for buyers, the company and for employees and stakeholders, and is the basic approach to create new markets and 
demand. The aim of the BOS is to make the competition irrelevant by reforming the industry boundaries. As a result, there is created a new and uncontested market space of new demand and high profitable growth.

\subsection{Recommendations}

The industry needs to follow the some basic considerations while adopting the BOS. Blue Ocean Strategy also entitles to some limitations and risks. The organization should think the existed risks and limitations while implementing the BOS. The organization should have the credibility and validity for the acceptance of the BOS making many assumptions about how companies currently operate which are arguable. Its foundation is so poor that its credibility is in serious question. The organizations should reconsider the integrity of the analytical tool existed in the BOS, consult with the business experts to adopt the BOS, perform SWOT (Strengths, Weakness, Opportunity, Threats) analysis to decide whether it will adopt BOS or not, finally the BOS should be justified again for its great appeal in the present competitive business world.

\subsection{Conclusion}

The BOS is an approach for developing sustainable profitable frameworks and creating innovational markets with a majority of new customers. It is a perfect solution for present companies to be sustainably successful. From the discussion, it is very clear that the BOS has a great impact to take the organization beyond the normal competition and make the organization a unique one. Besides its great advantages, there are some disadvantages too. That's why, the organization needs to perform SWOT analysis and consult with the experts to evaluate the feasibility of implementing BOS while following the BOS that will ensure the ultimate success for the organization and long-term sustainability.

\section{Acknowledgements}

The research work has noteworthy assistance of Dr. Ramón Sanguino Galván, Professor, Dr. Ascension Barroso Martinez, Assistant Professor, and Dr. Tomás M. Bañegil Palacios, Professor, Department of Business Management and Sociology, Faculty of Economics and Business Sciences, University of Extremadura, Spain. Again, would convey gratitude to the Journal reviewers who reviewed the manuscript and gave valuable comments as well as to the Editorial board of IOSR Journals for their constructive suggestions for further improvement.

\section{References}

[1]. Abu-Jarad, I., Yusof, N., \& Nikbin, D. (2010). A Review Paper on Organizational Culture and Organizational Performance. International Journal of Business and Social Science, 1(3), 26-46.

[2]. Agadoni, L. \& Agadoni, L. (2016). Importance of the BOS to a Busines. eHow. Retrieved 16 April 2016, from http://www.ehow.com /info_7743376_importance-blue-ocean-strategy-business.html

[3]. Agnihotri, A. (2015). Extending boundaries of BOS. Journal of Strategic Marketing, 1-10.http://dx.doi.org/10.1080/0965254x.2015 1069882

[4]. Ahmad, M. (2012). Impact of Organizational Culture on Performance Management Practices in Pakistan. Business Intelligence Journal, $5(1), 50-55$

[5]. Aithal, P. \& Kumar, P. (2015). Black Ocean Strategy - A Probe into a New Type of Strategy Used for Organizational Success. GEInternational Journal of Management Research, 3(8), 45-65.

[6]. Aluko, M. (2013). The Impact of Culture on Organizational Performance in Selected Textile Firms in Nigeria. Nordic Journal of African Studies, 12(2), 164-179.

[7]. Aspara, J., Hietanen, J., Parvinen, P., \& Tikkanen, H. (2008). An Exploratory Empirical Verification of Blue Ocean Strategies: Findings from Sales Strategy. In Eighth International Business Research (IBR) Conference. Dubai.

[8]. Awadh, A. \& Saad, A. (2013). Impact of Organizational Culture on Employee Performance. International Review of Management and Business Research, 2(1), 168-175.

[9]. Bartel, A. (2004). Human Resource Management and Organizational Performance: Evidence from Retail Banking. Industrial and Labor Relations Review, 57(2), 181-203.

[10]. Basri, J., Ghadzali, M., \& Ismail, M. (2011). BOS: Application in Universiti Sains Malaysia Library. Jurnal PPM, 5. Retrieved From Http://Eprints.Usm.My /26112/1/Blue_Ocean_Strategy.Pdf

[11]. Berry, G. (2015). Why the Business Model Canvas Complements BOS. NHL Nogeschool.

[12]. Blue Ocean Strategy is an excellent website for BOS (https://www .blueoceanstrategy.com/).

[13]. Borgianni, Y., Cascini, G., \& Rotini, F. (2012). Investigating the Patterns of Value-Oriented Innovations in BOS [Abstract]. International Journal of Innovation Science, 4(3), 123-142.http://dx.doi.org/10.1260/1757-2223.4.3.123

[14]. Bourletidis, D. (2014). The Strategic Model of Innovation Clusters: Implementation of BOS in a Typical Greek Region. Procedia Social and Behavioral Sciences, 148, 645-652. http://dx.doi.org/10.1016/j.sbspro.2014.07.093

[15]. Bowlby, R. (2012). Living the Future: Organizational Performance Assessment. Journal of Library Administration, 52(6-7), 626-652. http://dx.doi.org/10.1080/01930826.2012.707958

[16]. Buisson, B. \& Silberzahn, P. (2010). Blue Ocean or Fast-Second Innovation? A Four-Breakthrough Model to Explain Successful Market Domination [Abstract]. Int. J. Innov. Mgt., 14(03), 359-378. http://dx.doi.org/10.1142/s1363919610002684

[17]. Burke, A., Stel, A., \& Thurik, R. (2009). Blue Ocean versus Competitive Strategy: Theory and Evidence. Erim Report Series Research in Management. Retrieved from http://hdl.handle.net/1765/16037

[18]. Burke, A., Stel, A., \& Thurik, R. (2010, May). Blue Ocean vs. Five Forces. Harvard Business Review, 28.

[19]. Butler, C. (2008). Planning with BOS in the United Arab Emirates [Abstract]. Strat. Change, 17(5-6), 169-178. http://dx.doi.org/10 $.1002 / \mathrm{jsc} .824$ 
[20]. Canopus Business Management Group. (2016). Characteristics of a Good BOS. Collaborat.com. Retrieved 16 April 2016, from http://www.collaborat.com/characteristics-of-a-good-blue-ocean-strategy/

[21]. Chang, S. (2010). Bandit cellphones: A BOS [Abstract]. Technology in Society, 32(3), 219-223. http://dx.doi.org/10.1016/j.techsoc .2010 .07 .005

[22]. Cleverism, (2015). Strategic Framework: Understanding BOS. Retrieved 16 April 2016, from http://www .entrepreneurialinsights.com /understanding-blue-ocean-strategy-strategic-framework/

[23]. Cooke, F. (2001). Human resource strategy to improve organizational performance: a route for firms in Britain?. International Journal of Management Reviews, 3(4), 321-339. http://dx.doi.org/10.1111/1468-2370.00071

[24]. Dehkordi, G., Rezvani, S., \& Behravan, N. (2012). BOS: A Study over a Strategy Which Help the Firm to Survive From Competitive Environment. International Journal of Academic Research in Business and Social Sciences, 2(6), 477.

[25]. Deloach, J. \& Thomson, J. (2014, February). Governance and Operational Performance. Durham: Committee of Sponsoring Organization of the Treadway Commission (COSO).

[26]. Dobre, O. (2013). Employee motivation and organizational performance. Review of Applied Socio- Economic Research, 5(1), 53-60.

[27]. Fairholm, M. (2009). Leadership and Organizational Strategy. The Innovation Journal: The Public Sector Innovation Journal, 14(1).

[28]. Gagnon, Y. \& Dragon, J. (n.d.). The impact of technology on organizational performance. The Journal of Public Sector Management, $28(1), 19-31$.

[29]. Gandellini, G. \& Venanzi, D. (2011). Purple Ocean Strategy: How to Support SMEs' Recovery. Procedia - Social and Behavioral Sciences, 24, 1-15. http://dx.doi.org /10.1016/j.sbspro.2011.09.017

[30]. Garvin, D. \& Roberto, M. (2007). Change through persuasion. Harvard Business Review, 1-64.

[31]. Gavrea, C., Ilieș, L., \& Stegerean, R. (2011). Determinants of Organizational Performance: The Case of Romania. Management \& Marketing Challenges for the Knowledge Society, 6(2), 285-300.

[32]. Ghafoor Khan, R., Ahmed Khan, F., \& Aslam Khan, M. (2011). Impact of Training and Development on Organizational Performance. Global Journal of Management and Business Research, 11(7).

[33]. Giannoulis, C. \& Zdravkovic, J. (n.d.). Linking Strategic Innovation to Requirements: a look into BOS.

[34]. Green, K., Whitten, D., \& Inman, R. (2008). The impact of logistics performance on organizational performance in a supply chain context. Supply Chain Management: An International Journal, 13(4), 317-327. http://dx.doi.org/10.1108 /13598540810882206

[35]. Halligan, B. (2006). BOS: A Small Business Case Study.

[36]. Henri, J. (2004). Performance measurement and organizational effectiveness: bridging the gap. Managerial Finance, 30(6), 93-123. http://dx.doi.org/10.1108/03074350410769137

[37]. Herman, D. (2008). Marketing Article: The Limitations of Blue Oceans Strategies and an Unexpected Alternative. Marcommwise.com. Retrieved 16 April 2016, from http://www.marcommwise.com/article.phtml?id=911

[38]. Hsiao, Y. Creative Solutions from TRIZ for the Business Contradiction in ROS.

[39]. Hsu, F., Lee, H., \& Chi, T. Discovering Hidden BOS with KeyGraph Machine.

[40]. Hurduzeu, R. (2015). The Impact of Leadership on Organizational Performance. SEA - Practical Application of Science, III(1 (7), 289 294.

[41]. Jian-jun, W. \& Hai-min, W. (2007). An Explanation for BOS Based on Economics [Abstract]. China Industrial Economy, 5. Retrieved from http://en.cnki.com.cn/Article_en /CJFDTotal-GGYY200705011.htm

[42]. Kabukin, D. (2014, August 19). Reviewing the BOS. Is the BOS valid and reliable? (Master). University of Twente.

[43]. Keller, C. (2016). BOS Examples \& Return on Investment. Profitworks.ca. Retrieved 20 April 2016, from http://www.profitworks.ca /blog/371-blue-ocean-strategy-examples-and-return-on-investment

[44]. Kim, C., Yang, K., \& Kim, J. (2008). A strategy for third-party logistics systems: A case analysis using the BOS [Abstract]. Omega, 36(4), 522-534. http://dx.doi.org/10.1016/j.omega.2006.11.011

[45]. Kim, S., In, H., Baik, J., Kazman, R., \& Han, K. (2008). VIRE: Sailing a Blue Ocean with Value-Innovative Requirements [Abstract]. IEEE Softw., 25(1), 80-87. http://dx.doi.org/10.1109/ms.2008.27

[46]. Kim, W. \& Mauborgne, R. (1997, January-February). Value innovation: The strategic logic of high growth [Abstract]. Harvard Business Review, 82(7-8), 172-180. Retrieved from http://cat.inist.fr/?aModele=afficheN\&cpsidt=15903054

[47]. Kim, W. \& Mauborgne, R. (1999, January-February). Creating New Market Space. Harvard Business Reviw, 1-13.

[48]. Kim, W. \& Mauborgne, R. (2002). Charting your company's future [Abstract]. Harvard Business Review, 80(6), 76-83, 153. Retrieved from http://europepmc.org /abstract/med/12048996

[49]. Kim, W. \& Mauborgne, R. (2004a). BOS: How to Create Uncontested Market Space and Make the Competition Irrelevant. Harvard Business Review, (10), 71-81. Retrieved from http://www.qfinance.com/business-strategy-finance-library/blue-ocean-strategy-how-tocreate-uncontested-market-space-and-make-thecompetition-irrelevant

[50]. Kim, W. \& Mauborgne, R. (2004b). Value innovation: The strategic logic of high growth. Harvard Business Review, 82(7-8), 172180. Retrieved from http://cat.inist.fr $/$ ?aModele $=$ afficheN\&cpsidt $=15903054$

[51]. Kim, W. \& Mauborgne, R. (2005a). BOS: From Theory to Practice. California Management Review, 47(3), 105-121. http://dx.doi.org $/ 10.2307 / 41166308$

[52]. Kim, W. \& Mauborgne, R. (2005b). Value innovation: a leap into the blue ocean. Journal of Business Strategy, 26(4), 22-28. http://dx doi.org/10.1108/0275666051060852

[53]. Kim, W. \& Mauborgne, R. (2014, May). Blue Ocean Leadership: How to engage your employees and stop wasting everyone's time. Harvard Business Review, 61-70.

[54]. Kim, W. \& Mauborgne, R. (2014, November 13). The Mind Map of Blue Ocean Leadership. INSEAD Knowledge. Retrieved 18 April 2016, from http://knowledge.insead.edu /leadership-management/the-mind-map-of-blue-ocean-leadership-3690

[55]. Kim, W. \& Mauborgne, R. (2015). BOS, Expanded Edition: How to Create Uncontested Market Space and Make the Competition Irrelevant (Kindle Version). Boston: Harvard Business Review Press.

[56]. Kim, W. \& Mauborgne, R. (2015). Blue Ocean Strategy. Boston: Harvard Business Review Press.

[57]. Kim, W. \& Mauborgne, R. (2015, March). Red Ocean Traps: The mental models that undermine market-creating strategies. Harvard Business Review, 68-73.

[58]. Kim, W. \& Mouborgne, R. (2000, September-October). Knowing a winning business idea when you see one. Harvard Business Review, 129-137.

[59]. Kim, W. \& Mouborgne, R. (2003, January). Fair Process: Managing in the Knowledge Economy. Harvard Business Review, 1-11.

[60]. Kim, W. (2010). How strategy shapes structure. Strategic Direction, 26(2).

[61]. Koo, L., Koo, H., \& Luk, L. (2008). A pragmatic and holistic approach to strategic formulation through adopting balanced scorecard, SWOT analysis and BOS \&ndash; a case study of a consumer product manufacturer in China [Abstract]. IJMFA, 1(2), 127. http://dx.doi.org/10.1504/ijmfa.2008.021238

[62]. Koo, O. (n.d.). The Mind Map of Blue Ocean Leadership. INSEAD BOS Institute

DOI: $10.9790 / 487 X-1901030119 \quad$ www.iosrjournals.org $\quad 16 \mid$ Page


[63]. Kuratko, D. \& Audretsch, D. (2009). Strategic Entrepreneurship: Exploring Different Perspectives of an Emerging Concept. Entrepreneurship Theory and Practice, 33(1), 1-17. http://dx.doi.org/10.1111/j.1540-6520.2008.00278.x

[64]. Leavy, B. (2005). Value pioneering - how to discover your own "blue ocean": interview with W. Chan Kim and Renée Mauborgne [Abstract]. Strategy \& Leadership, 33(6), 13-20. http://dx.doi.org/10.1108/10878570510631611

[65]. Lesser, E. \& Storck, J. (2001). Communities of practice and organizational performance. IBM Syst. J., 40(4), 831-841. http://dx.doi.org $/ 10.1147 / \mathrm{sj} .404 .0831$

[66]. Li, S., Ragu-Nathan, B., Ragu-Nathan, T., \& Subba Rao, S. (2006). The impact of supply chain management practices on competitive advantage and organizational performance. Omega, 34(2), 107-124. http://dx.doi.org/10.1016/j.omega.2004.08.002

[67]. Lindič, J., Bavdaž, M., \& Kovačič, H. (2012). Higher growth through the BOS: Implications for economic policy [Abstract]. Research Policy, 41(5), 928-938. http://dx .doi.org/10.1016/j.respol.2012.02.010

[68]. Low, K. \& Ang, S. (2012). BOS (BOS) and Corporate Social Responsibility (CSR) [Abstract]. Encyclopedia of Corporate Social Responsibility. http://dx.doi.org /10.1007/978-3-642-28036-8

[69]. Luttman, R., Siren, P., \& Laffel, G. (1994). Assessing organizational performance [Abstract]. Quality Management in Health Care, 2(4), 44-45. http://dx.doi.org/10.1097/00019514-199422000-00008

[70]. Mankins, M. \& Steele, R. (2005, July-August). Turning Great Strategy into Great Performance. Harvard Business Review.

[71]. Meier, K. \& O'Toole, L. (2002). Public management and organizational performance: The effect of managerial quality. J. Pol. Anal. Manage., 21(4), 629-643. http://dx.doi.org /10.1002/pam.10078

[72]. Mi, J. (2015). BOS. Wiley Encyclopedia of Management, 1-1.

[73]. Mitchell, H. (2002, August). Strategic Worth of Human Resources: Driving Organizational Performance. Universalia.

[74]. Mohd Dali, N., Bin Nooh, M., Nawai, N., \& Mohammad, H. (n.d.). Is Halal Products Are More Expensive As Perceived By The Consumers? Muslimprenuers Challenges and Opportunities in Establishing a Blue Ocean Playing Field.

[75]. Moon, G. (2014). Want To Make Your Blog Stand Out? Use The BOS. CoSchedule Blog. Retrieved 20 April 2016, from http://coschedule.com/blog/blue-ocean-strategy/

[76]. Navis, C. \& Glynn, M. (2010). How New Market Categories Emerge: Temporal Dynamics of Legitimacy, Identity, and Entrepreneurship in Satellite Radio, 1990-2005. Administrative Science Quarterly, 55(3), 439-471. http://dx.doi.org/10.2189/asqu 2010.55 .3 .439

[77]. Neilson, G., Martin, K., \& Powers, E. (2008, June). The Secrets to Successful Strategy Execution. Harvard Business Review.

[78]. O’Gorman, P. (2008). Wii: Creating a Blue Ocean The Nintendo Way. Palermo Business Review, 2, 97-108.

[79]. Osabiya, B. (2015). The effect of employees motivation on organizational performance. Journal of Public Administration and Policy Research, 7(4), 62-75. http://dx.doi.org /10.5897/jpapr2014.0300

[80]. Park, T. \& Shaw, J. (2013). Turnover rates and organizational performance: A meta-analysis. Journal of Applied Psychology, 98(2), 268-309. http://dx.doi.org/10.1037/a0030723

[81]. Porter, M. (1996, November-December). What Is Strategy?. Harvard Business Review.

[82]. Porter, M. (2008, January). The Five Competitive Forces That Shape Strategy [Abstract]. Harvard Business Review, 78-93.

[83]. Raith, M., Staak, T., \& Wilker, H. (2016). A Decision-Analytic Approach to Blue-Ocean Strategy Development [Abstract]. Springer Link, Operations Research Proceedings 2007, 225-229. Retrieved from http://link.springer.com/chapter/10.1007/978-3-540-779032_35

[84]. Randall, R. (2015). W. Chan Kim and Renée Mauborgne dispel blue ocean myths [Abstract]. Strategy \& Leadership, 43(2), 11-14. http://dx.doi.org/10.1108/sl-01-2015-0007

[85]. Rašula, J., Vukšić, V., \& Štemberger, M. (2012). The Impact of Knowledge Management on Organisational Performance. Economic and Business Review, 14(2), 147-168.

[86]. Rosales, R. (2010). BOS: A whole new world.

[87]. Sani, A. (2012). Strategic Human Resource Management and Organizational Performance in the Nigerian Insurance Industry: The Impact of Organizational Climate. Business Intelligence Journal, 5(1), 8-20.

[88]. Saputri, M. \& Mulyaningsih, H. (2015). BOS for creating value innovation: A study over Kedai Digital in Yogyakarta, Indonesia. Journal of Administrative and Business Studies, 1(1). http://dx.doi.org/10.20474/jabs-1.1.3

[89]. Savage, C. \& Brommels, M. (2008). Innovation in medical education: how Linköping created a Blue Ocean for medical education in Sweden [Abstract]. Medical Teacher, 30(5), 501-507. http://dx.doi.org/10.1080/01421590801953760

[90]. Shahzad, F., Luqman, R., Khan, A., \& Shabbir, L. (2012). Impact of Organizational Culture on Organizational Performance: An Overview. Interdisciplinary Journal of Contemporary Research in Business, 3(9), 975-985.

[91]. Sharma, V., Seth, P., \& Niyazi, S. (2010). BOS. International Journal of Asian Business and Information Management, 1(1), $32-41$. http://dx.doi.org /10.4018/jabim.2010010104

[92]. Simons, S. \& Rowland, K. (2011). Diversity and its Impact on Organizational Performance: The Influence of Diversity Constructions on Expectations and Outcomes. Journal of Technology Management \& Innovation, 6(3), 171-183. http://dx.doi.org/10.4067/s07187242011000300013

[93]. Straub, D. (2009). Creating Blue Oceans of Thought via Highly Citable Articles. MIS Quarterly, 33(4), iii-vii.

[94]. Timothy C., O., Okwu, A., Akpa, V., \& Nwankwere, I. (2011). Effects of Leadership Style on Organizational Performance: A Survey of Selected Small Scale Enterprises in Ikosi-Ketu Council Development Area of Lagos State, Nigeria. Australian Journal of Business and Management Research, 1(7), 100-111.

[95]. Udegbe, S., Udegbe, M., Kehinde Ahmed, O., Ganiyat, A., \& Kareem, R. (2012). Impact of Business Communication on Organizational Performance in Nigerian Companies. Australian Journal of Business and Management Research, 2(1), 16-26.

[96]. Waiganjo, M., Mukulu, E., \& Kahiri, J. (2012). Relationship between Strategic Human Resource Management and Firm Performance of Kenya's Corporate Organizations. International Journal of Humanities and Social Science, 2(10), 62-70.

[97]. Wallace, C., Castaneda, M. and McGregor, P. (2009). BOS: Overcome Key Organizational Hurdles.

[98]. Wubben, E., Düsseldorf, S., \& Batterink, M. (2012). Finding uncontested markets for European fruit and vegetables through applying the BOS [Abstract]. British Food Journal, 114(2), 248-271. http://dx.doi.org/10.1108 /00070701211202421

[99]. Xiu-liang, H. (2007). Putting BOS into Practice and Strengthening Connotation Construction — On Strategic Choice in Building a Top-tier University of Nationalities in the World [Abstract]. Journal of Research on Education for Ethnic Minorities, 7. Retrieved from http://en.cnki.com.cn/Article_en/CJFDTotal-MZJY200706004.htm

[100]. Yang, C. \& Yang, K. (2011). An integrated model of value creation based on the refined Kano's model and the BOS [Abstract]. Total Quality Management \& Business Excellence, 22(9), 925-940. http://dx.doi.org/10.1080/14783363.2011.611358

[101]. Yang, J. (2012). Identifying the attributes of blue ocean strategies in hospitality [Abstract]. Int J Contemp Hospitality Mngt, 24(5), 701-720. http://dx.doi.org/10.1108/09596111211237255 


\section{APPENDICES}

A. Appendix 1

TABLE-4: HIGHER VS. LOWER ASSERTIVENESS FOR VALUES

\begin{tabular}{|c|c|}
\hline Higher assertiveness towards value tends to.. & Lower assertiveness towards value tends to.. \\
\hline $\begin{array}{l}\text { - sympathy for the strong value competition } \\
\text { - believe that anyone can succeed if he or she } \\
\text { tries hard enough } \\
\text { - direct and unambiguous communication that is } \\
\text { explicit in nature and lies to the point in } \\
\text { communication } \\
\text { - value expressiveness and revealing thoughts } \\
\text { and feelings, taking initiative, and what you } \\
\text { do more than who you are } \\
\text { - have relatively positive connotations for the } \\
\text { term aggression (e.g., aggression helps to } \\
\text { win), just-world belief, "can-do" attitude } \\
\text { - try to have control over the environment } \\
\text { - stress equity, competition, and performance } \\
\text { - emphasize results over relationships } \\
\text { - reward performance } \\
\text { - expect demanding and challenging targets } \\
\text { - believe that individuals are in control } \\
\text { - build trust on the basic of capabilities or } \\
\text { calculation }\end{array}$ & $\begin{array}{l}\text { - have sympathy for the weak, far more negative } \\
\text { connotations with the term aggression (e.g., } \\
\text { aggression leads only to negative outcomes), } \\
\text { and an unjust-world belief } \\
\text { - value cooperation, people and warm } \\
\text { relationships, ambiguity and subtlety in } \\
\text { language ambiguity and subtlety in language } \\
\text { and communication, detached and self- } \\
\text { possessed conduct, harmony with the } \\
\text { environment rather than control, and who you } \\
\text { are more than what you do } \\
\text { - associate competition with defeat and } \\
\text { punishment } \\
\text { - speak indirectly and emphasize "facesaving" } \\
\text { - stress equality, solidarity, and quality of life } \\
\text { - emphasize tradition, seniority and experience, } \\
\text { integrity, loyalty and cooperative spirit } \\
\text { - view "merit pay" as potentially destructive to } \\
\text { harmony } \\
\text { - build trust on the basis of predictability } \\
\text { - think of others as inherently worthy of trust }\end{array}$ \\
\hline
\end{tabular}

Adopted from Abu-Jarad, Yusof, \& Nikbin (2010)

B. Appendix 2

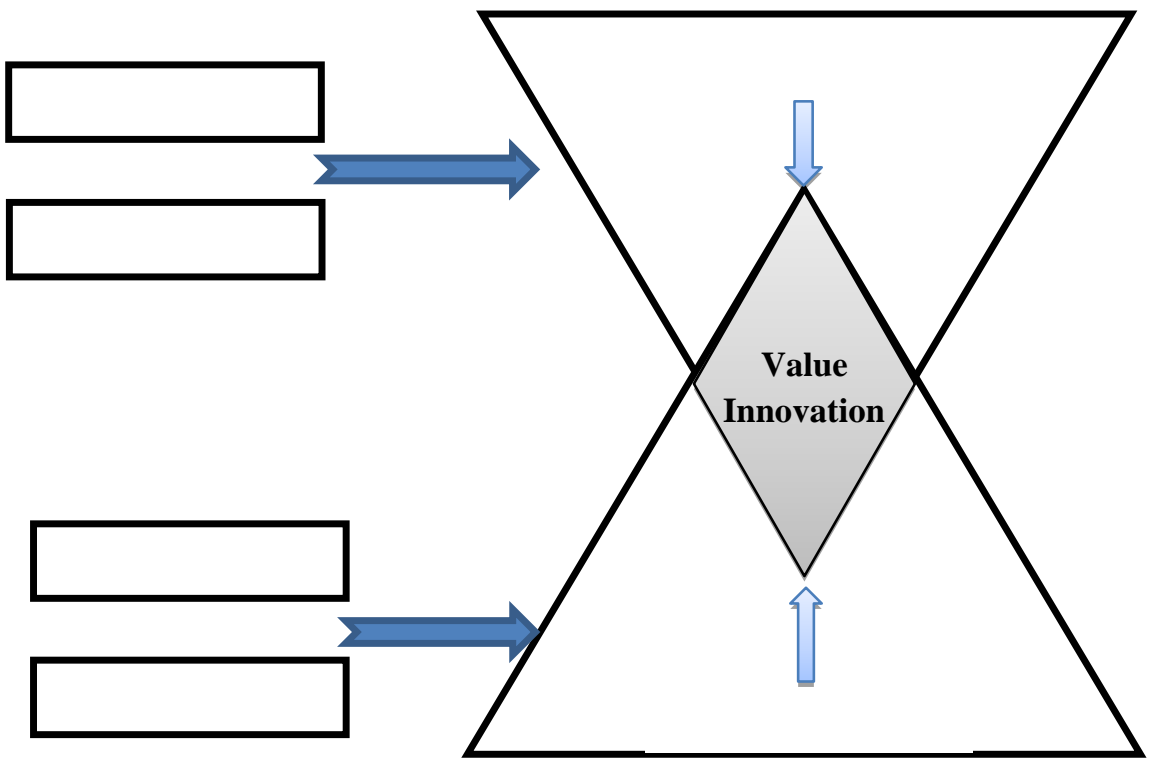

Fig.-9: Value innovation (Kim \& Mauborgne, 2010) 


\section{Appendix 3}

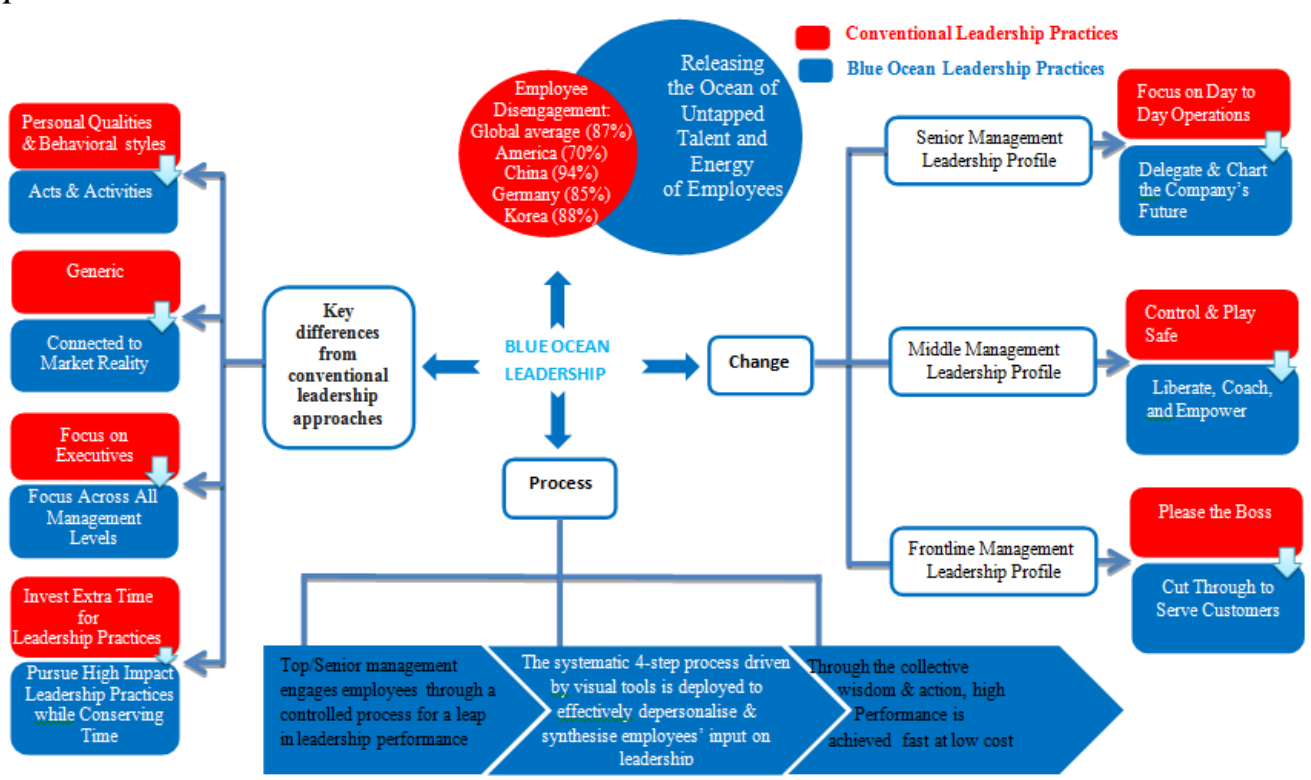

Fig.-10: The mind map of blue ocean leadership (koo, n.d.)

D. Appendix 4

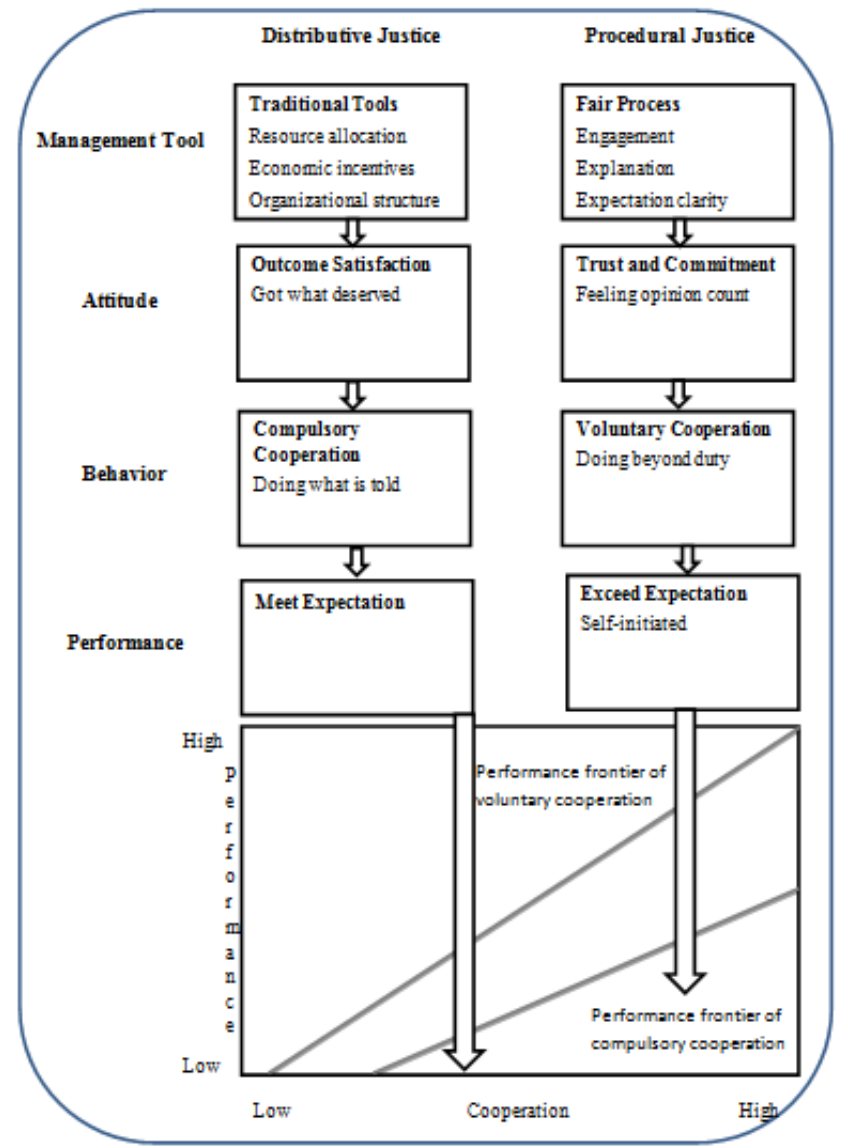

Fig.-11: Two complementary paths to performance (Kim \& Mouborgne, 2003, January, p. 11) 